\title{
THE CORONA VIRUS AND LABOR RIGHTS ISSUES: HOW DO WORKERS GET THEIR RIGHTS?
}

\author{
Diki Mardiansyah \\ Labor Protection Community, Semarang, Indonesia \\ Email: dikimardiansyah02@gmail.com
}

\begin{abstract}
The impact of Covid-19 is very broad and comprehensive in all human life. Students must learn from home, workers work from home, and all people worship from home. Really, a life that I never imagined before. Students complain about online lectures because assignments are increasing, internet quota runs out quickly, not to mention students from remote areas that are difficult to signal. This is clearly very troublesome for them. Even for workers who cannot work from home, the appeal to work from home is not valid. They are not office workers or lecturers who can work from home. They have to work on the streets, in the field, even in the fields or gardens. It is impossible for farmers to work from home. This can make us realize that we cannot eat money. Food needs will still be fulfilled by farmers. Referring to the right to decent work and livelihood, it is fitting for the Government to ensure that there is no Termination of Employment by the company and the provision of adequate wages in accordance with the provisions of the legislation in force. This paper will discuss the impact events of Covid-19 that have an impact on workers, especially workers. Not a few workers in various regions in Indonesia were laid off and laid off as a result of the Corona pandemic.
\end{abstract}

Keywords: Labor Rights; Layoff, Employment; Legal Protection; Government Policy

The Indonesian Journal of International Clinical Legal Education ISSN 2721-8368

DOI: $10.15294 /$ ijicle.v2i2.38328

(C) 2020 Authors. This work is licensed under a Creative Commons Attribution-ShareAlike 4.o International License. All writings published in this journal are personal views of the authors and do not represent the views of this journal and the author's affiliated institutions.

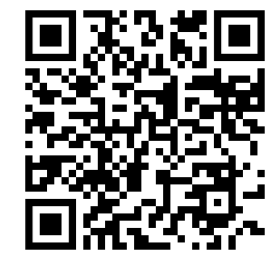




\section{Mardiansyah}

\section{INTRODUCTION}

The corona virus (Covid-19) has been the hottest topic since the last two weeks of January 2020 until April now. This virus suddenly became a terrible terror for the world community, including Indonesia, especially after claiming the lives of hundreds of people in just two weeks. One thing that is most alarming is that the virus continues to search for prey, while the cure has not yet been found. This new type of corona virus began to come to the attention of the world community after on January 20, 2020, health authorities in Wuhan City, Hubei Province, China, said three people died in Wuhan after suffering from pneumonia caused by the virus.

Reporting from the Asian Nikkei Review, the news immediately troubled Chinese citizens who would travel back home to celebrate the Chinese New Year on January 25, 2020. This virus felt even more frightening for residents because it was linked to the Severe Acute Respiratory Syndrome (SARS) which killed nearly 650 people in China and Hong Kong in 2002 and 2003 ago. The new type of corona virus that is currently attacking the world community in medical terms is called the 2019 Novel Coronavirus (2019-nCoV). Quoted from the Center for Disease Control and Prevention, cdc.gov, corona virus is a type of virus that is identified as a cause of diseases of the respiratory tract, which was first detected to appear in Wuhan City, China. ${ }^{1}$

This virus is known to first appear in animal and seafood markets in Wuhan City. It was reported later that many patients were suffering from this virus and were apparently linked to the animal and seafood market. The first people to fall ill from this virus are also known to be traders in the market. Quoted from the BBC, BBC health and science correspondent Michelle Roberts and James Gallager said that in the animal and seafood wholesale markets wild animals such as snakes, bats and chickens were sold. They suspect that the new corona virus is almost certainly from a snake. It is also suspected that the virus spread from animals to humans, and then from humans to humans.

Until now, the Corona virus has spread to infect residents in Indonesia. As of April 10, 2020, 3152 positive Covid-19, 306 died, 282 recovered, and 2924 were confirmed. ${ }^{2}$ The amount is not small, the government must be really serious in handling this Corona pandemic. The government's step to break the Corona pandemic chain until now there are social distancing, physical distancing, are advised to remain at home. However, this step is not very effective. Every day there are 3000 positive patients more. Conversely, some researchers, positive Covid-19

1 https://bali.idntimes.com/health/medical/denny-adhietya/asal-muasal-danperjalanan-virus-corona-dari-wuhan-ke-seluruh-dunia-regional-bali/full

2 Kompas.com, current data Covid-19 
in Indonesia until now has reached thousands because of rapid tests / swab for all citizens in Indonesia.

The impact of Covid-19 is very broad and comprehensive in all human life. Students must learn from home, workers work from home, and all people worship from home. Really, a life that I never imagined before. Students complain about online lectures because assignments are increasing, internet quota runs out quickly, not to mention students from remote areas that are difficult to signal. This is clearly very troublesome for them. Even for workers who cannot work from home, the appeal to work from home is not valid. They are not office workers or lecturers who can work from home. They have to work on the streets, in the field, even in the fields or gardens. It is impossible for farmers to work from home. This can make us realize that we cannot eat money. Food needs will still be fulfilled by farmers.

For workers, especially laborers, the existence of this pandemic makes their fate sad. Some are terminated from work (PHK), some have their rights reduced, some have their salary deducted, and so on. In this case, the government can be said to have failed to protect workers, especially laborers. Not a few workers in various regions who have to accept the fate of leaving his job. Food needs must still be met, while employment and income are gone. People confused about what to eat? According to the philosopher Cicero, "The safety of the people is the highest law". The government must be able to save its citizens from starvation and so that people can still live. Even Ghanaian president Akufo Addo said that, "We know how to revive the economy, what we don't know is to revive the dead."

If we look at the 1945 Constitution, there are articles that give rights to citizens. Article 27 paragraph 2 of the 1945 Constitution reads "The right of citizens to obtain a decent living. Every citizen has the right to live properly in Indonesia and make an effort to achieve that goal. Article 27 paragraph 2 of the 1945 Constitution reads "The right of citizens to get work. Citizens are entitled to get jobs to meet their needs. Specifically, the requirements regarding this work are regulated in the labor law". Article 28C paragraph 1 of the 1945 Constitution reads "The right of citizens to develop themselves. Every citizen has the right to fulfill his needs for welfare by developing himself". Article 28D paragraph 2 of the 1945 Constitution reads "The right of citizens to get compensation for their work. Citizens who work have the right to receive fair and appropriate compensation for what they do." Article $28 \mathrm{H}$ paragraph 1 of the 1945 Constitution reads "The right of citizens to live healthy. A prosperous life physically and mentally has the right to be obtained by every citizen through a healthy place to live and living environment. Health services are entitled to be obtained by every citizen."

For the reasons I have already outlined, I will write down some workers who were laid off because of the Corona virus. Why can a 


\section{Mardiansyah}

company do layoffs to its workers? Why can workers' rights be reduced as workers?

\section{PANDEMIC CORONA, GOVERNMENT FAILS TO PROTECT WORKERS FROM LAYOFFS}

President Joko Widodo's appeal when announcing a work from home (WFH) policy to reduce the spread of the COVID-19 pandemic to employers is actually clear and unequivocal: there must be no layoffs. ${ }^{3}$ Previously, on March 16, 2020 President Joko Widodo said that companies should not terminate employment. Following the appeal of President Joko Widodo, the government then issued other policies, including providing tax breaks. But after two weeks of appeals that were broadcast in the mass media, what happened was exactly the opposite. The DKI Jakarta Provincial Manpower, Transmigration and Energy Office noted that 14,697 companies had laid off 13,279 workers. 'Housing' is a term commonly used to refer to situations where workers do not need to work, but without getting paid. Another 3,348 companies have laid off 30,137 workers. Meanwhile, in Central Java at least 2800 workers have suffered the fate of having to be laid off.

Based on a statement from the Chair of the Advocacy Division of the Indonesian Legal Aid Foundation (YLBHI) Muhammad Isnur, assessing the number of workers who were laid off during the pandemic, and contrasted with Jokowi's statement, shows how weak the government's supervision and appeals from Jokowi are not enough at all, there are still many workers who were laid off affected Covid-19.

Many layoffs occur without a mechanism in accordance with Law 13 of 2003 concerning Manpower. In other words, legal defects. Because, "in the Manpower Act, layoffs should not be arbitrary. Layoffs are not legal until there is a decision on industrial relations disputes. Chairperson of the Indonesian Labor Alliance Congress (KASBI) Nining Elitos considers that layoffs are actually possible because of a letter made by the government, namely Circular of the Minister of Manpower Number M / 3 / HK.04 / III / 2020 concerning Worker / Labor Protection and Business Continuity in the Context of Prevention and Control of COVID19, especially Part II Point 4 which reads: "For companies that restrict business activities due to government policies in their respective regions -for the prevention and control of COVID-19, so as to cause some or all workers / laborers not to come to work, taking into account business continuity, changes in the amount and method of payment of wages for

3 https://tirto.id/saat-pandemi-corona-jokowi-gagal-melindungi-buruh-dari-phkeLlR 
workers / laborers are carried out in accordance with the agreement between employers and workers / laborers. "

The regulation is not in line with Law 13/2003. The law guarantees [the rights of] workers who are sick and in a state of emergency, why does the government issue SEs that regulate rights can be negotiated? Because of this Circular Letter, employers do not think more about committing more violations, including laying off workers. The government should protect them (laborers) and in this condition (Corona pandemic) the state guarantees the basic rights of the people. The government then has another so lution after the appeal is considered a breeze: the pre-employment card. On March 24, Jokowi said that the government had budgeted Rp10 trillion in funds this program. Nining felt this was not a solution because it did not stop the company from laying off, especially if there was an Omnibus Law that was still being discussed in this situation.

\section{CAUSES OF LABOR LAYOFFS IN THE CORONA PANDEMIC PERIOD}

Based on the Confederation of Indonesian Trade Unions (KSPI) there are four factors that cause the termination of employment or layoffs. The first factor is the availability of raw materials in the manufacturing industry which is running low. The raw materials are especially imported ones, such as from China and other countries exposed to the Corona virus outbreak. The industries that will be hit are labor intensive or labor intensive such as textiles, shoes, garments, food, beverages, electronic components, to automotive components. Reduced raw materials will make production decline. When production decreases, there is the potential for employee reductions by layoffs. ${ }^{4}$

The second factor is the weakening of the rupiah against the dollar. The rupiah exchange rate had weakened to 17 thousand per dollar. If this situation continues, labor-intensive and capital-intensive companies will be burdened with high production costs. Especially, companies that have to buy raw materials from imports. The company buys raw materials in dollars and sells in rupiah which continues to weaken. Coupled with the people's purchasing power which has declined sharply, companies will have difficulty raising the selling price. This will make the company lose. The third factor is the decline in tourist visits to Indonesia. Iqbal said that the industry had been hit since the beginning. The number of visitors to hotels, restaurants, tourist attractions, airports, and ports is said to have

4 Inayah, and Surisman, "Work Termination During The Covid-19 Pandemic in the Perspective of Positive Law in Indonesia." Legal Standing: Jurnal Ilmu Hukum 4(1), 2020, pp. 247-254. 


\section{Mardiansyah}

dropped dramatically due to the COVID-19 outbreak. There are concerns in the near future there will be massive layoffs in the tourism industry.

The last factor was the drop in oil prices and the composite stock index. As a result of falling world oil, Indonesia's income from crude oil exports also fell. World crude oil fell to the level of US \$ 30 per barrel, far from the assumption of Indonesian oil prices or ICP in the 2020 APBN of US $\$ 63$ per barrel. This situation is said to have caused the State Budget to not be realized. The impact is further, the country's income is reduced, social assistance will also be less. Could be, the cost of coping with corona will be reduced. When social assistance and company profits are reduced, while massive layoffs are in sight, the fate of workers will be even worse. The composite stock index called Iqbal also continued to fall. Domestic companies, for example the food industry, are at risk of loss because the value of their shares has fallen. Previously, DKI Jakarta's Manpower, Transmigration and Energy Office noted that 162,416 workers were laid off and laid off without receiving wages or unpaid leave due to the effects of the Corona virus.

\section{LAYOFFS IN VARIOUS AREAS OF INDONESIA}

1. West Java

The Department of Manpower and Transmigration (Disnakertrans) of West Java Province noted that up to April 5, 2020, there were 5,047 workers who had been laid off. Workers are exposed to layoffs because their industries or workplaces have been hit by the impact of the corona pandemic or COVID-19. Data shows that as of 5 April 2020, the number of companies or industries affected by COVID-19 was 1,476 companies / industries. ${ }^{5}$ And the number of workers affected by COVID-19 was 53,465 and then 5,047 workers were affected Laid off The number of workers / laborers in West Java that were dismissed due to corona impact was 34,365 people and the number of workers / laborers laid off was 14,053 people.

\section{Central Java}

As many as 24,240 workers in Central Java have been laid off and forced to be laid off by the company due to the outbreak of the corona virus. Since April 6, 2020, 191 companies in the Central Java region with 148,791 employees have been affected by the corona pandemic. Central Java Governor Ganjar Pranowo asked all affected employees to immediately register a Pre-Employment Card prepared by the provincial government of Central Java.

5 https://bisnis.tempo.co/read/1329303/industri-terpukul-corona-5-047-buruh-dijabar-kena-phk 


\section{East Java}

Based on the statement of Emil Dardak, Deputy Governor of East Java, there are currently at least 3,315 workers in his area who have been laid off due to the Corona virus pandemic (Covid-19). In addition, Emil said there were around 20 thousand workers in East Java who were laid off. Of the number of workers laid off, 1,633 of them are Indonesian Migrant Workers (PMI) or Indonesian Workers (TKI) who have returned to Indonesia. ${ }^{6}$

Meanwhile, other sources said that the Corona virus outbreak in East Java affected 18,009 workers. From 18,009 workers, 1,923 people were laid off and 16,086 were temporarily laid off by the company. ${ }^{7}$ East Java Governor Khofifah Indar Parawansa said workers who were laid off or laid off for a while came from 29 different companies in East Java. The 29 companies are scattered in several regencies / cities in East Java. The majority of companies that laid off or imposed layoffs were in the hotel and industrial sectors.

\section{Bali}

In Bali, around 400 workers were laid off, while 17,000 employees were laid off. Head of the Bali Provincial Manpower Agency Ida Bagus Ngurah Arda explained, based on preliminary data, as many as 17,000 formal workers were laid off during the corona pandemic. While as many as 400 workers were laid off. The workers, he said, came from the tourism sector such as hotels and restaurants. The Bali government is currently continuing to collect data on workers affected by the corona outbreak. Arda said formal workers affected by the corona pandemic would receive pre-employment cards. Cardholders will get intensive money of $\mathrm{Rp} \mathrm{600,000.00} \mathrm{for} \mathrm{four} \mathrm{months.} \mathrm{They} \mathrm{will} \mathrm{also} \mathrm{receive} \mathrm{training}$ from the Job Training Institute (LPK). Online training is included which costs around Rp. 1 million to be borne by the central government.

\section{Central Kalimantan}

Reduction of workers to layoffs occurred in Central Kalimantan. Central Kalimantan's Manpower and Transmigration Office, Syahril Tarigan, said that this step was the aftermath of the spread of the corona virus or Covid-19. Launching Between, as many as 848 workers from 18 companies in Central Kalimantan were temporarily laid off until laid off. ${ }^{8}$

\footnotetext{
https://www.cnnindonesia.com/ekonomi/20200410073350-92-492305/imbascorona-3315-pekerja-di-jatim-kena-phk

7 https://news.detik.com/berita-jawa-timur/d-4969250/18009-tenaga-kerja-di-jatimterdampak-covid-19-di-phk-hingga-dirumahkan

8 https://regional.kompas.com/read/2020/04/09/06100071/phk-karyawan-disejumlah-daerah-imbas-wabah-corona-mana-saja-
} 


\section{Mardiansyah}

6. Jambi

The Department of Labor Cooperatives (Disnakerkop) and the UMKM of Jambi City noted that 749 employees were laid off due to the beating of the business community due to the corona pandemic. Head of the Industrial Relations Office of Manpower and SMEs in Jambi City Ramayanti explained that the hundreds of employees consisted of several business sectors. But that number can still increase, because not all companies that lay off employees report.

\section{DKI Jakarta}

Head of the DKI Jakarta Transmigration and Energy Manpower Office Andri Yansyah said that 162,416 workers had reported being laid off and laid off. Hundreds of thousands of workers came from 18,045 companies. Andri said, the details of 30,137 workers from 3,348 companies were laid off. While 132,279 workers from 14,697 companies were laid off without pay. The Manpower Office will report the data to the Coordinating Ministry for Economic Affairs and the Indonesian Ministry of Manpower. The data will later be verified by the central government to be given incentives through the Workers' Card program for workers.

\section{LAYOFFS IN TERMS OF LAW}

In article 151 paragraph (1) of Law No. 13 of 2003 concerning Manpower (Manpower Act) stated that employers, workers / laborers, trade unions /labor unions, and the government, with all efforts must strive to avoid termination of employment (PHK). Furthermore, article 151 paragraph (2) explains that if termination of employment is unavoidable, it must be negotiated by the employer and the trade union/labor union or with the worker/labor if the worker/labor concerned is not a member of a trade union/labor union. ${ }^{9}$

The provisions of article 151 paragraph (1) and paragraph (2) mean that layoffs must not be done unilaterally but must first go through negotiations. Then, if the results of the negotiations do not result in agreement, the employer can only terminate the employment relationship with the workers / laborers after obtaining a determination from the industrial relations dispute resolution agency. Thus the provisions of article 151 paragraph (3) of the Manpower Act. The industrial disputes settlement institutions referred to are labor mediation, labor conciliation, labor arbitration and industrial relations courts. This is regulated further

9 See Imas Novita Juaningsih, "Analisis Kebijakan PHK Bagi Para Pekerja Pada Masa Pandemi Covid-19 di Indonesia." 'ADALAH 4(1), 2020, 189-196; Richard Kennedy, "Legal Discourse on Manpower During COVID-19 Outbreak." Law Reform 16(1), 2020, pp. 70-86. 
in Law No. 2 of 2004 concerning Settlement of Industrial Relations Disputes (PPHI Law). ${ }^{10}$

Termination of employment without the establishment of an industrial relations settlement institution will be null and void by law. That is, legally the dismissal is considered as not yet happening (article 155 paragraph 1 of the Manpower Act). And as long as the decision of the industrial relations dispute resolution agency has not been determined, both employers and workers must continue to carry out all their obligations (article 155 paragraph [2] of the Manpower Act). Workers must continue to work and employers must pay their wages as long as there is no decision from the industrial relations dispute resolution agency. Employers can make exceptions in the form of suspension to workers/labors who are in the process of terminating employment by continuing to pay wages along with other rights commonly received by workers/labors (article 155 paragraph [3] of the Manpower Act). ${ }^{11}$

What should be done if the company still does not want to accept the employee and still does not want to pay the salary? According to article 96 of the PPHI Law, if in the first trial it is evident that the employer is proven to have not carried out his obligations, then the presiding judge must immediately give an interim decision in the form of an order to the employer to pay wages along with other rights commonly received by the worker/labor concerned. If the interlocutory verdict is not carried out by the employer, the presiding judge orders the confiscation of collateral in an industrial relations court ruling. The interlocutory verdict cannot be submitted for resistance and / or cannot be used as a remedy.

Laid off the arrangement of the three letters is a very frightening specter for workers. How not. The fate of the workers is almost certain to fall apart if they get a letter of termination of employment. Status-wise, someone who was laid off no longer bears the title of labor in his former place of work. If you don't get a new job soon, the threat of unemployment is in sight. Economically, those who were laid off could lose their source of livelihood.

Layoffs or termination of employment are indeed not illegal goods in labor law in Indonesia. UU no. 13 of 2003 concerning Manpower (the Manpower Law) defines layoffs as termination of employment relations due to a certain matter that results in the termination of rights and obligations between workers and employers.

Normatively, there are two types of layoffs, namely voluntary layoffs and involuntary layoffs. There are several reasons for the termination of employment in the Labor Law. Voluntary layoffs, for example, are defined as the resignation of workers without coercion and

10 https://www.hukumonline.com/klinik/detail/ulasan/c16996/phk-sepihak/

11 See also Mohamad Anwar, "Dilema PHK dan Potong Gaji Pekerja Di Tengah Covid-19." 'ADALAH 4(1), 2020, 173-178. 


\section{Mardiansyah}

pressure. Similarly, due to the expiration of the contract period, did not pass the probation period (probation), entered retirement age and workers died. Voluntary layoffs can occur partly because workers make serious mistakes such as stealing or embezzling company money or committing immoral acts or gambling in the work environment. During this time, the reason for layoffs because of serious mistakes was regulated in article 158 of the Manpower Act. This article was once submitted by a judicial review to the Constitutional Court. The Constitutional Court in its decision stated that the grave wrongdoing alleged to workers must be proven in advance by a criminal court ruling in a general court.

In addition, involuntary layoffs can also occur because workers violate work agreements, PKB or PP. Companies that are also conducting merger, merger and or status change, have the option to maintain or terminate employment. Now, for the context of this involuntary termination of employment, the employment relationship between employers and workers it will only end after it is determined by the Industrial Relations Dispute Settlement Agency. Not so with voluntary layoffs. Almost all workers certainly do not want to be laid off. Therefore, if the employer breaks the employment relationship, the worker will desperately defend his job and rights. In practice, the Industrial Relations Court (PHI) which was given authority by Law No. 2 of 2004 concerning Settlement of Industrial Relations Disputes (PPHI Law) indeed handled PHK disputes more than other disputes, namely rights, interests and disputes between trade unions. This indicates the rampant practice of involuntary dismissal.

One of the reasons that employers often use to lay off workers is the mistake of workers because they are considered to have abused office facilities. Strangely, there are some cases where employers still use Article 158 of the Manpower Act as the basis for severing employment. Trend or development is also evident in industrial relations disputes. For layoffs for example. In addition to what has been firmly stipulated in the law, the reason for the dismissal also turns out to be developing in practice. Of course, it must be with the agreement of the parties, namely workers and employers, which are usually contained in a work agreement or PKB.

Look at the experience of Dewi Anggraeni, Secretary General of the Garuda Indonesia Cabin Crew Association (IKAGI) who accompanied several flight attendants who were laid off by Garuda Indonesia because they failed to lose weight. Fortunately, the Jakarta PHI panel of judges who tried this case stated that the company had made regulations and imposed sanctions unilaterally so that the layoffs became illegal.

Another mode of development of layoffs is the actions of entrepreneurs who rent out their companies, both assets and workers, to other entrepreneurs. Thus, the fate of workers becomes hung. This is currently being advocated by the Indonesian Trade Union Movement 
(GSBI) against workers in Cikarang. This is a new mode because the Manpower Act only recognizes layoffs for companies that merge, merge or change their status. Hermawanto, a public lawyer for LBH Jakarta emphasized that now there is even a practice of renting out company and labor assets like this.

The most recent is the case of layoffs because workers follow certain religious sects. This was experienced by three employees who were fired by the management agency of a famous mosque in Jakarta because they were caught following the flow of Al Qiyadah Al Islamiyah, led by Mushadeq. In the decision made at the end of October 2007, clearly a legal source online, the three employees were said to have no right to severance pay or any reward. It is noteworthy that the Manpower Law clearly states that workers or workers must not be treated discriminatively. So, in practice, the reason for laying off someone indeed continues to grow beyond the formulation of legislation.

\section{FORM OF LEGAL PROTECTION FOR WORKERS LAID OFF}

Before discussing the legal protection of workers who are terminated from work relations, it is necessary to review the employment relationship. Based on the provisions of article 1 number 15 of Act No. 13 of 2003, the meaning of work relations is "Relations between employers and workers / laborers based on work agreements, which have elements of work, wages and orders". The employment relationship occurs after the existence of an employment agreement between the worker and the employer, which is an agreement whereby the first party, the labor, commits himself to work by receiving wages to the other party, the employer, who is committed to employing the worker by paying wages. "On the other party" implies that the laborers doing the work are under the leadership of the employer.

Work relations are carried out by legal subjects. Legal subjects bound in this employment relationship are employers and workers. The meaning of worker /labors based on article 1 number 3 of Law No. 13 of 2003 namely "Everyone who works for a wage or other forms of remuneration." During the implementation of the employment relationship, it is possible to terminate the employment relationship. Either done on the initiative of the employer or on the initiative of the worker. Based on the provisions of article 1 number 25 of Law No. 13 of 2003 the meaning of termination of employment is "Termination of employment due to a certain matter which results in the end of rights and obligations between workers/labors and employers". Based on the provisions of article 150 of Law No. 13 of 2003, termination of employment includes termination of employment that occurs in a legal entity or not, owned by individuals, belonging to partnerships or legal 


\section{Mardiansyah}

entities, both private and state owned, as well as social businesses and other businesses that have management, and employ others by paying wages or rewards in other forms.

Termination of employment provides a psychological, economicfinancial effect for the worker and his family in maintaining their survival. Layoffs must be sought to be prevented. If layoffs cannot be prevented or avoided, then workers who are laid off by the employer in accordance with the reasons underlying the termination of employment will receive severance pay, long service awards and compensation money. All of which are intended to function as income guarantees. ${ }^{12}$

The termination of employment is related to income security for workers who have lost their jobs. It is necessary to create satisfactory regulations regarding procedures for terminating employment by taking into account the interests of employers and laborers as well as making appropriate and proper resolutions and imbued with noble values of Pancasila. $^{13}$

Rights for workers laid off. If layoffs cannot be avoided, then in accordance with the reasons underlying the layoffs, the employer is required to pay severance pay, and/or pay for work tenure that is adjusted to the work period and compensation for rights.

\section{WORK RELATED PROBLEMS BECAUSE OF THE COVID-19 PANDEMIC? 16 LBH-YLBHI OFFICE OPENS ONLINE LEGAL AID COMPLAINT POST}

The Indonesian government has established the status of the corona virus spread as a national disaster since 15 March 2020. The implications of the outbreak of the Covid - 19 pandemic in the field of labor are felt by laborers / workers. Workers' wages are only calculated per hour, work only 15 (fifteen) days in a month, granting unpaid leave until termination of employment.

The outbreak of the corona virus also resulted in reduced shopping center visitors and delivery of goods choked up. Unilateral actions taken by the company to workers will lead to new legal problems, in which the worker / worker becomes a party that is severely disadvantaged. Day

12 Heri Kurniawansyah, et al. "Konsep Kebijakan Strategis Dalam Menangani Eksternalitas Ekonomi dari Covid-19 Pada Masyarakat Rentan di Indonesia." Indonesian Journal of Social Sciences and Humanities 1(2), 2020, pp. 130-139.

13 Djumadi, Perjanjian Kerja Hukum Perburuhan Perjanjian Kerja, Raja Grafindo Perkasa, Banjarmasin, 1995, pp. 88-89; FX Djumialdji,, \& Wiwoho Soejono, 1987, Perjanjian Perburuhan dan Hubungan Perburuhan Pancasila, PT. Bina Aksara, Jakarta, pp. 76-78 
laborers, contract workers and outsourcers whose bargaining positions are weakest and are easily dismissed. Therefore, we deeply regret the release of Circular of the Minister of Manpower Number M / 3 / HK.04 / III / 2020 concerning Worker/Labor Protection and Business Continuity in the Context of Prevention and Countermeasure for Covid -19 dated March 17, 2020.

In Roman II number 4 states, "... then changes in the amount and payment of wages of workers / laborers are carried out in accordance with the agreement between employers and workers / laborers". This provision is very detrimental to workers because workers because workers are in an unequal position and as a result must receive improper wages. Whereas proper wages are protected human rights and are the responsibility of the government to advance them, as stipulated in the International Convention on Economic Social and Cultural Rights which has been ratified by Indonesia. Under these conditions, workers are confused and worried because they are afraid that their wages will be cut. Employers will easily decide on layoffs.

Referring to the right to decent work and livelihood, it is fitting for the Government to ensure that there is no Termination of Employment by the company and the provision of adequate wages in accordance with the provisions of the legislation in force.

The wage system has been regulated in Article 90 of Law No. 13 of 2003 on Manpower (UUK), which states that "employers are prohibited from paying wages lower than the minimum wage as referred to in Article 89". So, it is clear employers are prohibited from paying workers' wages below the minimum wage as long as there is no deferral of wages and still paying wages in accordance with the provisions of the legislation in force. Likewise, Article 151 paragraph (1) of the Law on Manpower states that "employers, workers / laborers, trade unions / labor unions, and the government must make every effort to prevent termination of employment". Thus, the government has the obligation to make efforts so that no workers / workers are laid off.

Based on the above, YLBHI and 16 LBH Offices opened an Online Legal Aid Complaint Post related to the Impact of the Covid-19 Pandemic on Labor. This post aims to protect workers' / workers' normative rights, ensure the protection of the right to work and decent livelihood for workers, prevent abuse from the company, and reject the government's hands off attitude towards workers/workers' fate.

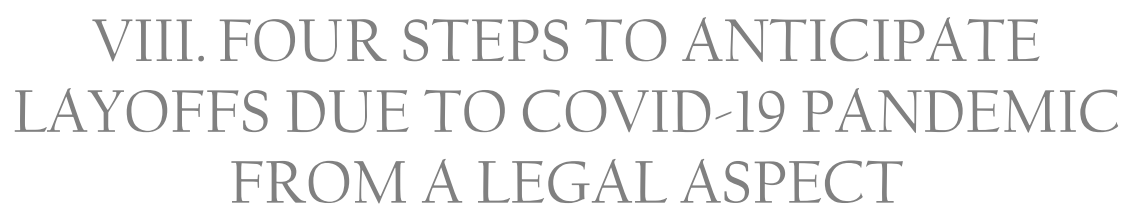

The impact of the COVID-19 global pandemic is very significant for the Indonesian economy. The economic slowdown is projected to occur over 


\section{Mardiansyah}

the next 4-6 months. It could even take longer, because we have not been able to predict when this outbreak can be completely resolved. In the initial phase of this outbreak in Indonesia, the tourism, aviation, hospitality, retail and restaurant sectors were immediately hit. Impacts on other sectors will gradually be increasingly felt. This will certainly have an impact on the fate of workers. ${ }^{14}$

Even though President Joko "Jokowi" Widodo has asked employers not to make Termination of Employment (PHK), but this option is feared will still be pursued in the face of the current crisis. The current crisis situation may leave employers with no choice but to lay off because they have to reduce large-scale operational costs. But Law (Law) No. 13 of 2003 concerning Manpower has confirmed that layoffs should be the last step taken. Before conducting layoffs, the Manpower Law regulates how employers, laborers, trade unions, and governments must work together to prevent layoffs. Avoid layoffs. Employers, workers, trade unions and the government must be able to establish cooperation that anticipates layoffs. Here are four things you can do:

1. Conduct a two-way or bipartite dialogue. Employers and workers together with trade unions need to engage in transparent dialogue early on in anticipating employment conditions due to the COVID19 pandemic. Companies that because of their industrial nature require the presence of workers must regulate the work system by prioritizing occupational safety and health. In addition, bipartite dialogue also needs to discuss anticipation of the worst conditions of work relations between them such as efficiency, working hours arrangements, and division of labor. This dialogue is the main door to build mutual understanding to face the impact of the COVID-19 pandemic both for companies and workers.

2. Arrange employment policies in a COVID-19 pandemic situation. This policy must respond to any changes that occur as a result of the COVID-19 pandemic towards the employee's work system. These changes include the application of the work from home system, social distancing, restrictions on public transportation facilities, and limited lockdowns that are currently being implemented by several local governments. At present there are 9 regions that have received approval to implement Large Scale Social Restrictions (PSBB) such as Jakarta then Bogor in West Java and South Tangerang in Banten. The government, in this case the Ministry of Manpower must be active in providing policy information for work and conducting regular policy reviews. Policies that can be applied for example policies to reduce working days and hours, dismiss / lay off workers, and so on. In addition, the government also needs to carry out an employment mitigation plan in the face of worsening work situations due to the economic

14 https://theconversation.com/4-langkah-antisipasi-phk-akibat-pandemi-covid-19dari-segi-hukum-135471 
crisis as a result of the COVID-19 pandemic. This can be done by implementing government programs that can absorb a large workforce and skills development support programs such as the provision of Pre-Employment Cards for people who have just graduated from school and are looking for work.

3. Realize and monitor the implementation of incentive packages for employers and workers to survive. The government has issued incentive packages for entrepreneurs such as exempting or reducing tax payments and budget grants for the small business sector. The government itself plans to provide a stimulus of $\mathrm{Rp} 2$ trillion to increase the purchasing power of cooperatives and Micro, Small and Medium Enterprises (MSMEs). In addition, social incentives are also prepared by the government for workers who are laid off or unable to work like informal sector workers. This incentive takes the form of direct assistance and discounts for the needs of facilities provided by the government (electricity and water). This policy needs to be realized and monitored so that it is right on target.

4. Conduct a three-way dialogue (tripartite) between employers, workers / trade unions and the government. In parallel with the provision of incentive packages for employers and workers, in this difficult situation the government must also be able to mediate dialogue between employers and workers and trade unions both to prevent layoffs. The role of the government can be sought as a mediator in finding solutions agreed by both parties, especially related to the fulfillment of workers' rights, if layoffs are unavoidable. In this case the government can form a PHK Handling Task Force so that more responses to the problems of employers and workers during this pandemic can be anticipated and resolved early.

Risk of Massive layoffs. The International Labor Organization (ILO) says the COVID-19 pandemic will affect certain groups that are vulnerable to the labor market and a decline in the number of jobs, as well as the quality of work including wages and social protection, and even the ILO predicts that in the worst conditions there will be nearly 25 million unemployment throughout the world due to this pandemic. The layoff option could be the last step to be taken. This step is a bad situation, especially for workers. Layoffs will have a very serious impact on the economy of the worker's family. On the other hand, employers are also in a difficult position because they have to fulfil obligations for employees who have been laid off. The task of the government and us in completing the COVID-19 pandemic is still long. Rescue of citizens and suppressing the spread of the virus are the main focus at this time. We hope that the COVID-19 pandemic can be resolved immediately so that the government with the support of all parties can immediately restore the economy. 


\section{Mardiansyah}

\section{CONCLUSION}

By seeing the realities that exist today. then, the government should be able to protect workers from threats and fate in layoffs. The government should not only urge companies not to lay off workers. Decisive steps from the government are needed so workers are not laid off in a pandemic situation. Referring to the right to decent work and livelihood, it is fitting for the Government to ensure that there is no Termination of Employment by the company and the provision of adequate wages in accordance with the provisions of the legislation in force.

\section{REFERENCES}

Anwar, M. (2020). Dilema PHK dan Potong Gaji Pekerja Di Tengah Covid-19. 'ADALAH, 4(1), 173-178.

Djumadi, D. (1995). Perjanjian Kerja Hukum Perburuhan Perjanjian Kerja. Banjarmasin: Raja Grafindo Perkasa.

Djumialdji, FX., \& Soejono, W. (1987). Perjanjian Perburuhan dan Hubungan Perburuhan Pancasila. Jakarta: PT. Bina Aksara.

Halim, A.R., \& Gultom, S.S. (1987). Sari Hukum Perburuhan Aktual. Jakarta: Pradnya Paramita.

Inayah, I., \& Surisman, S. (2020). Work Termination During The Covid19 Pandemic in The Perspective of Positive Law in Indonesia. Legal Standing: Jurnal Ilmu Hukum, 4(1), 247-254.

Juaningsih, I. N. (2020). Analisis Kebijakan PHK Bagi Para Pekerja Pada Masa Pandemi Covid-19 di Indonesia. 'ADALAH, 4(1), 189-196.

Kartasapoetra, G. (1992). Hukum Perburuhan di Indonesia Berdasarkan Pancasila. Jakarta: Sinar Grafindo.

Kartasapoetra, G. (1983). Hukum Perburuhan Pancasila Bidang Pelaksanaan Hubungan Kerja. Bandung: Armico.

Kartasapoetra, G., \& Widianingsih, G. R. (1982). Pokok-pokok Hukum Perburuhan. Bandung: Armico.

Kennedy, R. (2020). Legal Discourse on Manpower During COVID-19 Outbreak. Law Reform, 16(1), 70-86.

Kurniawansyah, H., Amrullah, A., Salahuddin, M., Muslim, M., \& Nurhidayati, S. (2020). Konsep Kebijakan Strategis Dalam Menangani Eksternalitas Ekonomi dari Covid-19 Pada Masyarakat Rentan di Indonesia. Indonesian Journal of Social Sciences and Humanities, 1(2), 130-139.

Widodo, H., \& Judiantoro, J. (1992). Segi Hukum Penyelesaian Perselisihan Perburuhan. Jakarta: Rajawali Pers. 
[...] https://bali.idntimes.com/health/medical/denny-adhietya/asalmuasal-dan-perjalanan-virus-corona-dari-wuhan-ke-seluruhdunia-regional-bali/full

[...] https://tirto.id/saat-pandemi-corona-jokowi-gagal-melindungiburuh-dari-phk-eLIR

[...] https://bisnis.tempo.co/read/1329303/industri-terpukul-corona-5047-buruh-di-jabar-kena-phk

[...] https://www.cnnindonesia.com/ekonomi/20200410073350-92492305/imbas-corona-3315-pekerja-di-jatim-kena-phk

[...] https://news.detik.com/berita-jawa-timur/d-4969250/18009tenaga-kerja-di-jatim-terdampak-covid-19-di-phk-hinggadirumahkan 
Mardiansyah

Oิ 